\title{
Potencial de uso de um resíduo de lodo de efluentes de indústrias de papel em matrizes cimentícias
}

\author{
Use potential of a paper sludge waste from \\ tissue paper industries in cementitious \\ materials
}

\author{
Vanessa Giaretton Cappellesso ${ }^{1}$, Natália dos Santos Petry ${ }^{1}$, \\ Camila Salvi Malacarne ${ }^{1}$, Gustavo Filipe dos Santos ', \\ Ana Paula Kirchheim ', Angela Borges Masuero ', \\ Denise Carpena Coitinho Dal Molin ${ }^{1}$, \\ Erich David Rodriguez ${ }^{2}$
}

\footnotetext{
${ }^{1}$ Laboratório de Materiais e Tecnologia do Ambiente Construído - PPGEC/NORIE/UFRGS, Porto Alegre, RS, Brasil.

${ }^{2}$ Universidade Federal de Santa Maria - UFSM, Santa Maria, RS, Brasil

e-mail: vgcappellesso@gmail.com,nataliapetry@yahoo.com.br, camila.smalacarne@gmail.com, gustavofilipedossantos@yahoo.com.br, anapaula.k@gmail.com, angela.masuero@ufrgs.br,dmolin@ufrgs.br, erichdavidrodriguez@gmail.com
}

\begin{abstract}
RESUMO
Essa pesquisa teve por finalidade avaliar um resíduo de lodo de efluentes de indústrias de papel quanto à potencialidade de emprego em matrizes cimentícias. Verificou-se a composição química do resíduo e realizaram-se misturas com adições de 0,5 e 10\%, em relação à massa de cimento. As matrizes cimentícias foram analisadas por meio de calorimetria isotérmica, resistência à compressão, resistência à tração na compressão diametral, absorção de água por capilaridade, densidade de massa aparente e módulo de elasticidade dinâmico. Os resultados obtidos não foram satisfatórios, visto que a adição do resíduo à matriz apresentou aumento no consumo de cimento para atingir a resistência requerida e aumento no consumo de água para manutenção da consistência.
\end{abstract}

Palavras-chave: argamassa, matrizes cimentícias, resíduo industrial, lodo de papel.

\begin{abstract}
The purpose of this study was to evaluate a paper sludge waste obtained from tissue paper industries regarding its potential for use in cementitious materials. The chemical composition of the waste was assessed and mixtures were made with $0 \%, 5 \%$ and $10 \%$ additions of the material, by mass of cement. The cement matrices were analysed experimentally by isothermal calorimetry, compressive strength and tensile strength by diametric compression, water absorption by capillarity, apparent mass density and dynamic modulus of elasticity. The results obtained were not satisfactory, since the addition of the paper sludge waste showed an increase in the cement consumption to reach the required compressive strength, as well as a rise in water consumption in order to maintain the mortar consistency.
\end{abstract}

Keywords: mortar, cementitious materials, industrial waste, paper sludge waste.

\section{INTRODUÇÃO}

A cadeia produtiva do cimento Portland é um dos setores com maior potencial para empregar resíduos ou subprodutos de outros processos industriais [1]. A utilização de resíduos como adição ou substituição parcial ao cimento Portland permite a redução do conteúdo de clínquer, podendo auxiliar na minimização dos impactos ambientais associados à produção de cimento e também do passivo ambiental das empresas geradoras de resíduo. Encontrar alternativas viáveis, técnica e economicamente, para destinação de resíduos industriais deve ser encarado, portanto, como um desafio comum para a indústria do cimento e para os geradores de resíduos. 
Dentre essas indústrias com quantidades consideráveis de resíduos gerados se enquadra a indústria de papel, cujo resíduo foi avaliado neste trabalho. Em 2015, o Brasil ocupou o $9^{\circ}$ lugar no ranking dos maiores produtores mundiais de papel, produzindo 10,4 milhões de toneladas [2]. Segundo ANGUTI [3], a produção brasileira de papéis para fins sanitários correspondeu a $23 \%$ deste total, somando 2,4 milhões de toneladas. Estima-se que o volume de lodo de efluentes gerado seja equivalente a aproximadamente $1 \%$ da produção total de papel $[4,5,6]$.

Durante o processo de fabricação do papel ocorre a geração de grande quantidade de resíduo em forma de lodo com alto teor de sólidos em suspensão. O resíduo de lodo de papel (RLP) é o produto final do tratamento destas águas residuais nas estações de tratamento de efluentes [7, 8]. O RLP é gerado em vários processos envolvidos na fabricação do papel, e as grandes quantidades produzidas tornam a destinação deste um problema à indústria e ao meio ambiente. Usualmente o RLP é disposto em aterros, o que pode originar uma série de problemas ambientais, como a contaminação de águas subterrâneas e a degradação do solo [7, 9].

Em geral, um RLP fresco contém cerca de 50\% de sua massa em forma de água, bem como caulim, pasta de celulose, carbonato de cálcio e metais pesados residuais [8]. PERA e AMROUZ [10] demonstraram pioneiramente em 1998 que quando um lodo de papel contendo o argilomineral caulinita em sua composição é submetido a um tratamento térmico controlado a caulinita presente pode ser transformada em metacaulim, um material com alta reatividade pozolânica. Diversos estudos desenvolvidos desde então demonstraram o potencial desse resíduo como material pozolânico [11, 12, 13, 14].

FRÍAS et al. [14] avaliaram a pozolanicidade de um RLP com 20,83\% de caulinita calcinado a $700{ }^{\circ} \mathrm{C}$ por duas horas comparada a um metacaulim comercial, a partir de um método acelerado que consistia em colocar estes materiais em contato com uma solução saturada de cal $(75 \mathrm{ml})$ a $40{ }^{\circ} \mathrm{C}$ por 1, 7, 28 e 91 dias. No fim destes períodos a concentração de cal restante na solução era avaliada e a diferença em relação ao conteúdo inicial representava o teor de cal fixado pelo material em solução. Os autores observaram resultados de pozolanicidade do RLP bastante similares ao metacaulim comercial em todas as idades analisadas.

VEGAS et al. [12] analisaram diferentes condições de calcinação para um RLP com $21 \%$ de caulinita. Dentre os processos de calcinação avaliados, com queimas a $700{ }^{\circ} \mathrm{C}$ e a $750{ }^{\circ} \mathrm{C}$ por duas e cinco horas e a $800{ }^{\circ} \mathrm{C}$ por duas horas, a que resultou em maior pozolanicidade foi a queima a $700{ }^{\circ} \mathrm{C}$ por duas horas. Aumentando a temperatura ou tempo de queima a pozolanicidade era reduzida. Os autores ainda avaliaram o efeito da substituição de $10 \%$ de um cimento Portland referência sem adições por RLP na resistência à compressão em argamassas, sendo observado um aumento de 3,6\% na resistência aos 28 dias para o cimento com o resíduo.

Outras formas de utilização deste resíduo além de como material cimentício suplementar também são abordadas na literatura. No estudo de VIEIRA et al. [7], por exemplo, desenvolvido no Rio de Janeiro, foi estudada a utilização de RLP como adição à matéria prima de tijolos cerâmicos, em um teor de $10 \%$. O resíduo foi calcinado em conjunto com a argila caulinítica empregada na fabricação dos tijolos em um forno adaptado, a uma temperatura de $750{ }^{\circ} \mathrm{C}$. Os resultados de resistência à compressão obtidos para os tijolos com adição, apesar de inferiores aos de referência, atenderam aos requisitos mínimos das normativas brasileiras.

AHMADI e AL-KHAJA [15] investigaram a substituição do agregado miúdo do concreto por RLP em teores de até 10\% de substituição em massa, em um traço 1:3:6 (cimento:agregado miúdo:agregado graúdo). Os autores observaram uma diminuição na resistência à compressão dos blocos a medida que aumentavam o teor de adição de resíduo, e também um aumento no consumo de água. Foi concluído que um teor máximo de 5\% de RLP pode ser utilizado em substituição a areia, resultando em um concreto com resistência à compressão de $8 \mathrm{MPa}$ aos 28 dias.

Ressalta-se que os lodos provenientes de indústrias de papel podem possuir, no entanto, diferentes composições mineralógicas, que variam em função do processo industrial empregado, da proporção entre o papel virgem e o papel reciclado utilizado como matéria prima e dos componentes inorgânicos presentes. As condições de calcinação também desempenham um papel importante nas características do produto obtido. Por esta razão, a aplicação deste material requer uma compreensão básica da natureza do lodo bruto e calcinado, pois isso terá uma influência direta sobre seu comportamento posterior [16].

O presente estudo tem como objetivo, portanto, avaliar o potencial de utilização como adição à matriz cimentícia de um lodo de estação de tratamento de efluentes (ETE) proveniente de uma indústria de papel para fins sanitários ou tissue, com matéria prima constituída exclusivamente de papel reciclado. Foi realizada uma caracterização inicial do resíduo a fim de determinar a viabilidade e a forma de utilização mais 
adequadas deste material e o tratamento prévio necessário e, posteriormente, foi desenvolvido um programa experimental para avaliar o desempenho do resíduo em pasta, quanto ao calor de hidratação, e em argamassa, quanto à sua influência em propriedades mecânicas e de durabilidade.

\section{MATERIAIS E MÉTODOS}

\subsection{Materiais empregados}

\subsubsection{Resíduo de efluente de lodo de papel tissue (RLP)}

O resíduo utilizado, denominado RLP, é proveniente da Estação de Tratamento de Efluentes (ETE) de uma indústria de papel tissue (papéis utilizados para fins sanitários e que possuem baixa gramatura) localizada na região noroeste do Rio Grande do Sul. Este resíduo é retirado diretamente da ETE com alto teor de umidade e deve passar por processo de secagem e calcinação para ser utilizado como adição em matrizes cimentícias. A matéria prima desta indústria constitui-se exclusivamente de papel reciclado, não sendo utilizada polpa celulósica na produção do papel. A caracterização química e física será apresentada dentro dos resultados, pois faz parte do programa experimental como pré-estudo para determinação do emprego adequado do RLP dentro da matriz cimentícia.

\subsubsection{Aglomerante}

Utilizou-se como aglomerante o Cimento Portland de alta resistência inicial (CPV ARI). A Tabela 1 apresenta as características químicas, físicas e mecânicas do cimento empregado, de acordo com o fabricante.

Tabela 1: Caracterização do aglomerante de acordo com o fabricante.

\begin{tabular}{l|l|l}
\hline COMPOSIÇÃO QUÍMICA - Teor (\% em massa) \\
\hline CARACTERISTICAS AVALIADAS & CP V ARI & LIMITES NORMATIVOS \\
\hline Óxido de magnésio (MgO) & 2,7 & $\leq 6,5$ \\
\hline Trióxido de Enxofre (SO3) & 3,0 & $\leq 4,0$ \\
\hline Perda ao fogo & 3,6 & $\leq 4,5$ \\
\hline Resíduo Insolúvel & - & - \\
\hline CARACTERIZAÇÃO FíSICA & \multicolumn{2}{|l}{} \\
\hline CARACTERÍSTICAS AVALIADAS & CP V ARI & LIMITES NORMATIVOS \\
\hline Finura \#200 & 0,3 & $\leq 6,0$ \\
\hline Finura \#325 & 1,7 & - \\
\hline Massa específica (g/cm $\left.{ }^{3}\right)$ & 3,15 & - \\
\hline Início de pega (min) & 249 & $\geq 60$ \\
\hline Fim de pega (min) & 323 & $\leq 600$ \\
\hline Área específica (cm ${ }^{2 / g)}$ & 4628 & $\geq 3000$ \\
\hline RESISTÉNCIA Ȧ COMPRESSÁO (Mpa) & \\
\hline IDADE & CP V ARI & LIMITES NORMATIVOS \\
\hline 1 & 21,1 & $\geq 14$ \\
\hline 3 & 37,6 & $\geq 24$ \\
\hline 7 & 42,5 & $\geq 34$ \\
\hline 28 & 47,9 & - \\
\hline & \multicolumn{2}{|l}{} \\
\hline
\end{tabular}

\subsubsection{Agregado miúdo}

O agregado miúdo utilizado tem origem quartzosa. O mesmo teve a distribuição granulométrica definida de acordo com a ABNT NBR 248 [17], tendo se enquadrado dentro dos limites da zona utilizável da ABNT NBR 7211 [18]. A dimensão máxima característica é 2,40mm e módulo de finura 2,22. Para a determinação da massa específica utilizou-se como base a ABNT NBR NM 52 [19], tendo apresentado como resultado $2,51 \mathrm{~g} / \mathrm{cm}^{3}$.

\subsection{Programa experimental}

A fim de verificar o comportamento da adição do RLP, optou-se por adotar a metodologia empregada por MOURA [20], MASUERO [21], GIORDANI [22] e PETRY [23]. Estes estudos buscaram uma destinação 
para resíduos empregando-os em matrizes cimentícias, sendo feita uma caracterização inicial com o objetivo de entender as características do material e a forma de utilização mais adequada, seguida de testes de propriedades mecânicas e de durabilidade quando inseridos em uma matriz cimentícia.

\subsubsection{Caracterização do RLP}

Com a finalidade de encontrar o emprego adequado para o resíduo analisado dentro da matriz cimentícia foram feitos os ensaios de termogravimetria, difração de raios-X e granulometria a laser.

A análise termogravimétrica foi conduzida em um Analisador termogravimétrico da marca TA Instruments modelo Q50 com capacidade de aquecimento até $1000{ }^{\circ} \mathrm{C}$ a uma taxa de aquecimento de 20 ${ }^{\circ} \mathrm{C} / \mathrm{min}$., em atmosfera de ar sintético com fluxo de $90 \mathrm{ml} / \mathrm{min}$.

A composição química do resíduo foi determinada por difração de raios-X, realizada com um difratômetro modelo Philips X'Pert MPD, com tubo cerâmico modelo PW 3373/00 e detector proporcional modelo PW 3011/10, raios-X CuKa $\left(1=1,5418 \AA\right.$ ), com passo de $0,05^{\circ}$.

A análise de distribuição do tamanho de partícula foi realizada por difração a laser em um equipamento CILAS, Particle Size Analyser, modelo 1180 Liquid (CILAS, Orleans, França). A amostra foi dispersa em isopropanol, sendo feito um tratamento ultrassônico prévio, para promover a dispersão das partículas, com duração de 60 segundos.

\subsubsection{Produção das argamassas}

Foram produzidos três traços: um intermediário (1:3), um rico em cimento $(1: 1,5)$ e um pobre em cimento $(1: 4,5)$, todos expressos em uma relação de cimento:areia seca, em massa. Os teores de adição do resíduo avaliados foram de $0 \%, 5 \%$ e $10 \%$ em relação à massa do cimento, conforme também estudado por [11], [12] e [15]. Para a realização da dosagem de água, e posterior confecção dos corpos de prova, as misturas de argamassa foram realizadas conforme a ABNT NBR 7215 [24], sendo o índice de consistência determinado de acordo com a ABNT NBR 13276 [25].

Nesta dosagem, fixou-se a consistência em $250 \pm 10 \mathrm{~mm}$, variando apenas a quantidade de água para cada mistura. Após a moldagem, os corpos de prova ficaram acondicionados em temperatura ambiente nas primeiras 24 horas, cobertos com sacos plásticos. Posteriormente, foram desmoldados e armazenados em câmara úmida sob temperatura de $23 \pm 2{ }^{\circ} \mathrm{C}$ e umidade maior que $95 \%$, onde permaneceram até as datas dos ensaios aos 7 e 28 dias de idade. Na Tabela 2 consta o proporcionamento dos materiais utilizado na moldagem das argamassas.

Tabela 2: Proporcionamento dos materiais.

\begin{tabular}{|c|c|c|c|c|c|c|}
\hline \multicolumn{2}{|c|}{ PROPORCIONAMENTO } & \multirow[t]{2}{*}{ CIMENTO (g) } & \multirow{2}{*}{$\begin{array}{l}\text { AGREGADO } \\
\text { MIÚDO }(\mathrm{g}) \\
1500\end{array}$} & \multirow[t]{2}{*}{$\begin{array}{l}\text { ADIÇÃO } \\
\text { RLP (g) }\end{array}$} & \multirow{2}{*}{\begin{tabular}{|l} 
ÁGUA/CIMENTO \\
0,38
\end{tabular}} & \multirow{2}{*}{\begin{tabular}{|l|}
$\begin{array}{l}\text { CONSISTÉNCIA } \\
(\mathrm{mm})\end{array}$ \\
255 \\
\end{tabular}} \\
\hline \multirow[b]{3}{*}{$0 \%$} & 1,5 & & & & & \\
\hline & 3 & \multirow[b]{2}{*}{1000} & 3000 & \multirow[b]{2}{*}{0} & 0,52 & 245 \\
\hline & 4,5 & & 4500 & & 0,79 & 250 \\
\hline \multirow[b]{3}{*}{$5 \%$} & 1,5 & \multirow[b]{3}{*}{1000} & 1500 & \multirow[b]{3}{*}{50} & 0,40 & 255 \\
\hline & 3 & & 3000 & & 0,57 & 255 \\
\hline & 4,5 & & 4500 & & 0,81 & 245 \\
\hline \multirow[b]{3}{*}{$10 \%$} & 1,5 & \multirow[b]{3}{*}{1000} & 1500 & \multirow[b]{3}{*}{100} & 0,47 & 250 \\
\hline & 3 & & 3000 & & 0,63 & 255 \\
\hline & 4,5 & & 4500 & & 0,85 & 260 \\
\hline
\end{tabular}

\subsubsection{Métodos de ensaio das matrizes cimentícias}

Para caracterizar as matrizes cimentícias no estado fresco foi realizado o ensaio de calorimetria isotérmica. O ensaio foi realizado em um microcalorímetro de condução do modelo Tam Air, da marca TA Instruments, com uma temperatura de estabilização de $25{ }^{\circ} \mathrm{C}$. O procedimento inicial foi a pesagem dos materiais conforme as proporções de substituição, mantendo relação água/cimento igual a 0,45 (esta relação foi escolhida por ser um valor médio entre as relações água/aglomerante encontradas nas dosagens das argamassas). Nas pastas que continham adições, foi feita uma mistura prévia do cimento e do RLP 
manualmente durante 30 segundos. Em seguida o material seco e a água foram misturados manualmente durante 30 segundos, e na sequência em um misturador automático na frequência de $10 \mathrm{mil}$ rpm durante 1 minuto. $\mathrm{O}$ ensaio foi mensurado durante 48 horas.

Foram realizados no estado endurecido os ensaios de resistência à compressão aos 7 e 28 dias de acordo com a ABNT NBR 5739 [26], resistência à tração na compressão diametral aos 28 dias de acordo com a ABNT NBR 7222 [27], absorção de água por capilaridade aos 7 e 28 dias pela ABNT NBR 9779 [28], densidade de massa aparente aos 7 e 28 dias pela ABNT NBR 13280 [29] e módulo de elasticidade dinâmico aos 28 dias pela ABNT NBR 15630 [30]. Para o ensaio de absorção de água por capilaridade, optou-se por impermeabilizar as laterais dos corpos de prova, conforme procedimento adaptado por VENQUIARUTO et al. [31], onde os autores propõem o selamento da superfície lateral dos corpos de prova, garantindo assim a absorção unidirecional e reduzindo as variabilidades decorrentes da evaporação de água pelas laterais do corpo de prova.

\section{RESULTADOS E DISCUSSÕES}

\subsection{Caracterização do RLP}

Logo após sua extração, o RLP foi seco em estufa a $100{ }^{\circ} \mathrm{C}$ para retirar sua umidade. A partir da diferença entre a massa inicial e a massa seca foi verificado que o RLP contém, em média, $60 \%$ de água em sua composição. Em seguida, foi feito o ensaio de termogravimetria (TGA) para analisar a composição química e o comportamento térmico do material. A Figura 1 representa as perdas de massa obtidas e a termogravimetria derivada (DTG) para o resíduo.

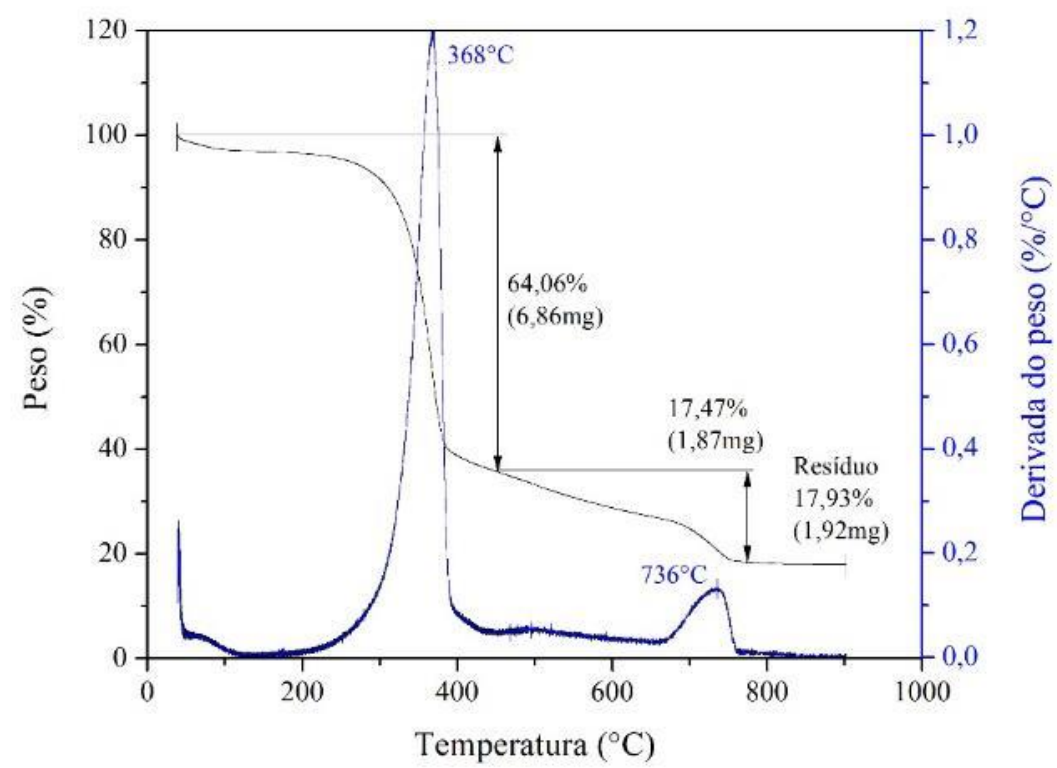

Figura 1: Termogravimetria do RLP.

Identifica-se na curva DTG um pico à temperatura de $368^{\circ} \mathrm{C}$, com perda de massa de $64,06 \%$, que se deve principalmente à despolimerização e consequente combustão das fibras ou fibrilas de material celulósico presentes no resíduo e remanescentes do processo de beneficiamento do papel [32, 33]. Segundo VIEIRA et al. [7] e SCHAFFER [34], todo o material orgânico é carbonizado até a temperatura de $400{ }^{\circ} \mathrm{C}$.

Outro pico aparece na DTG na temperatura de $738^{\circ} \mathrm{C}$. Essa perda de massa é atribuída à dissociação do anidrido carbônico do carbonato de cálcio $\left(\mathrm{CaCO}_{3}\right)$, que ocorre em temperaturas superiores a $600{ }^{\circ} \mathrm{C}$ [36], sendo totalmente decomposto à temperatura de $900{ }^{\circ} \mathrm{C}$, segundo VIEIRA et al. [7] e LOTHENBACH et al. [36]. Baseado nestes resultados, o resíduo foi calcinado a uma temperatura de $400{ }^{\circ} \mathrm{C}$ em uma mufla estática por duas horas para eliminar toda a matéria orgânica.

No intervalo de 450 a $600{ }^{\circ} \mathrm{C}$, onde acontece a perda de massa característica da conversão do argilomineral caulinita em metacaulinita, segundo KAKALI et al. [37] e SNELLINGS et al. [38], foi observada uma perda de massa pouco significativa. Isso difere o resíduo aqui estudado dos outros resíduos de lodo de papel encontrados na bibliografia [11,12], que continham, respectivamente, 29,2\% e 20,83\% de caulinita em sua composição. 
O difratograma do resíduo calcinado (RLPC) pode ser observado na Figura 2. A identificação das fases cristalinas presentes nas amostras foi realizada através do software X'Pert High Score, comparando os resultados obtidos através das análises dos picos principais de cada fase identificada nas fichas PDF (Powder Diffraction Files). Foi observada a presença exclusiva de carbonato de cálcio (PDF: 00-005-0586), o que corrobora os resultados encontrados no ensaio de termogravimetria.

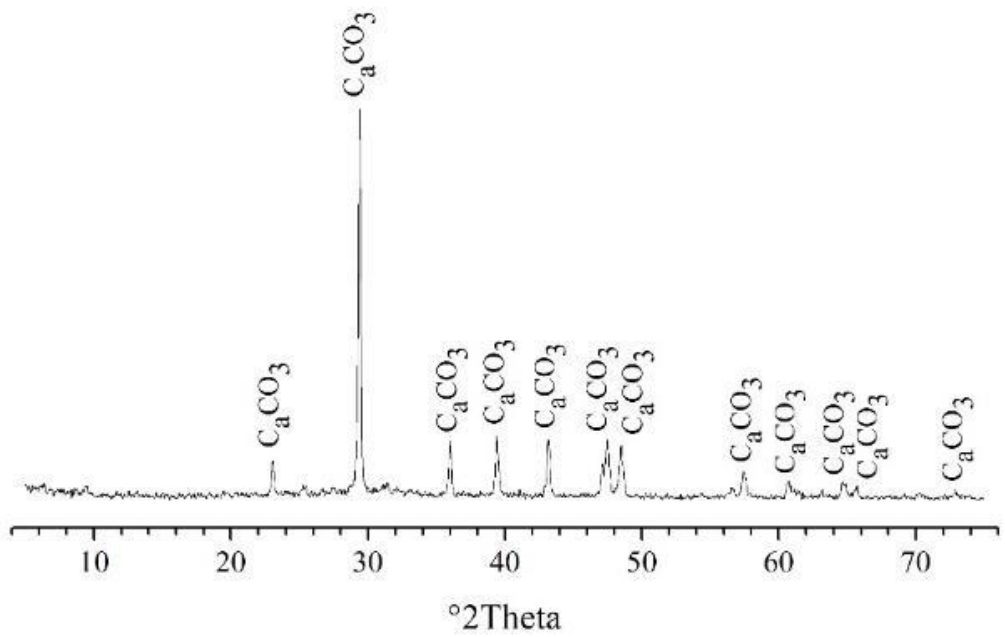

Figura 2: Difratograma obtido para o RLPC.

Executou-se a seguir o ensaio de granulometria a laser para verificar a distribuição granulométrica dos grãos do RLPC. A dimensão média obtida foi igual a 26,64 $\mu \mathrm{m}$, com D10 de 2,97 $\mu \mathrm{m}$, D50 de 27,03 $\mu \mathrm{m}$ e D90 igual a 48,95 $\mu \mathrm{m}$. O RLPC foi então moído durante 15 minutos com auxílio de um moinho de bolas, em um equipamento de cilindro horizontal preenchido parcialmente com esferas cerâmicas de diversos tamanhos. Após esse processo, houve uma redução de 50\% do diâmetro médio das partículas, para 12,91 $\mu \mathrm{m}$, e os parâmetros da curva de distribuição obtidos foram de $0,99 \mu \mathrm{m}, 7,12 \mu \mathrm{m}$, e 34,34 $\mu \mathrm{m}$ para D10, D50 e D90 respectivamente.

Devido à granulometria do resíduo ser bastante fina e em função de propriedades do próprio material, pode ocorrer aglomeração devido às forças de Van der Waals que provocam atração física entre as partículas. Na Figura 3, pode ser visto o resíduo aglomerado em forma de cachos por microscopia óptica, sendo mais agravante no resíduo moído durante 15 minutos (Figura 3b).

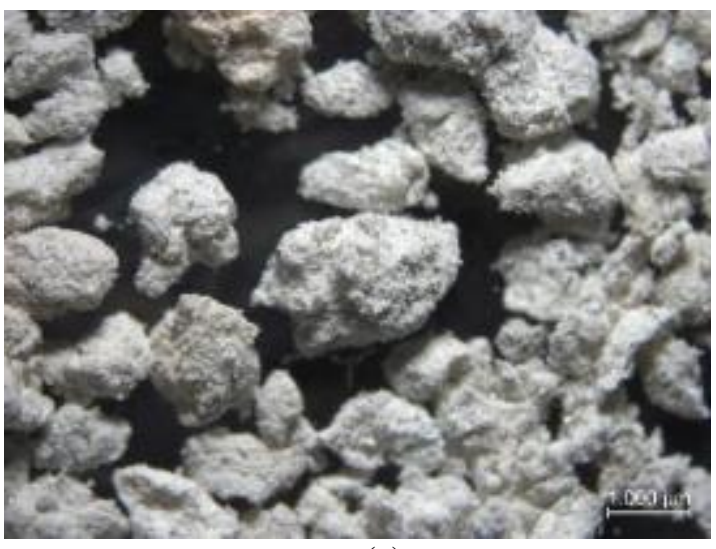

(a)

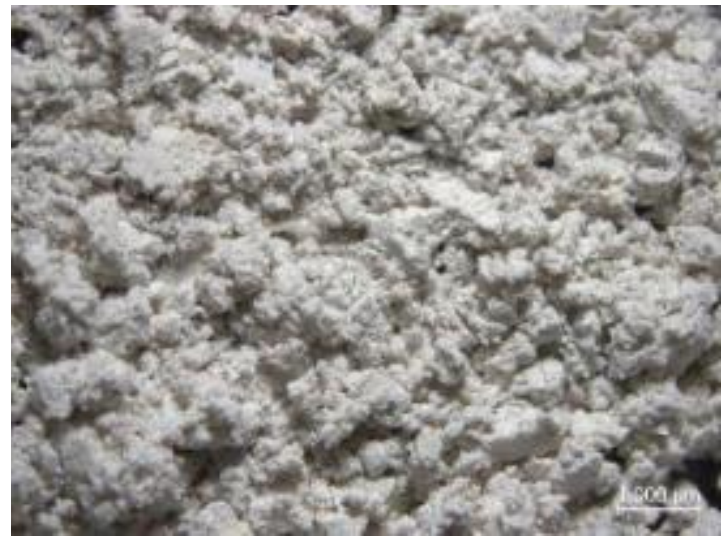

(b)

Figura 3: Microscopia ótica (a) RLPC sem moagem, (b) RLPC moído por 15 minutos.

\subsection{Ensaios na matriz cimentícia}

\subsubsection{Calorimetria isotérmica}

Os resultados de fluxo de calor $(\mathrm{mW} / \mathrm{g})$ e calor acumulado $(\mathrm{J} / \mathrm{g})$ foram normalizados de acordo com a massa de cimento inserida em cada amostra e estão demonstrados na Figura 4. 


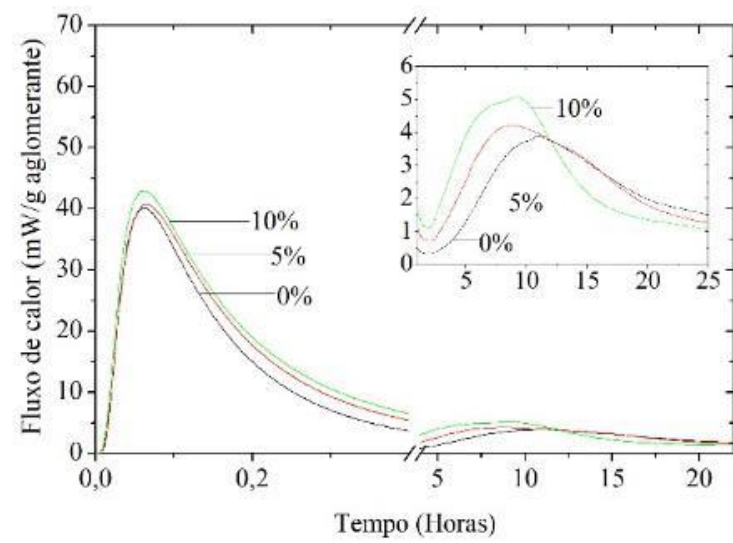

(a)

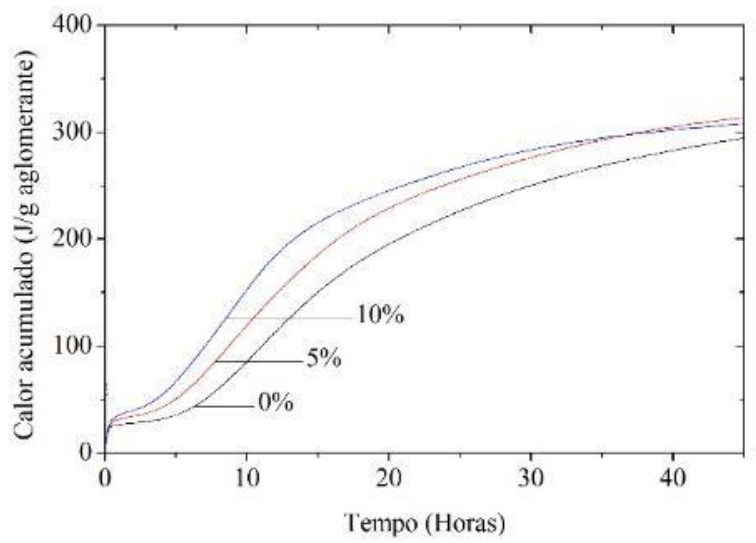

(b)

Figura 4: Calorimetria isotérmica (a) fluxo de calor em função do tempo; (b) calor acumulado em função do tempo.

Observa-se na Figura 4a a presença de um maior fluxo inicial de calor para as misturas com maiores teores de adição. Isto se deve a um efeito fíler decorrente da baixa granulometria do RLPC, responsável por proporcionar pontos de nucleação para os produtos de hidratação do cimento, como explicado por LOTHENBACH et al. [39]. Da mesma forma, no pico principal de hidratação o maior fluxo de calor foi obtido para a pasta com teor de $10 \%$ de adição e o menor para a pasta referência.

Além dos efeitos físicos pode ter ocorrido também um efeito químico visto que o resíduo possui grande proporção de $\mathrm{CaCO}_{3}$, como descrito no resultado de DRX, se assemelhando a um fíler calcário. A presença deste mineral pode ter auxiliado a acelerar a hidratação das fases aluminato do clínquer e a formação de monocarboaluminatos de cálcio proporcionando maiores picos e, consequentemente, deve contribuir para o aumento da resistência nas primeiras idades [40].

Em relação ao calor acumulado ao término das 48 horas de ensaio, a mistura com 5\% de RLPC foi a que apresentou maior calor acumulado, enquanto o traço referência apresentou o menor resultado. Nota-se uma maior diferenciação entre os fluxos de calor das misturas com diferentes teores de RLPC para o período inferior a 20 horas de ensaio, no qual o calor de hidratação é mais acentuado para o proporcionamento com $10 \%$ de adição, seguido do de $5 \%$ de adição e com menor calor liberado para a mistura com $0 \%$ de adição.

\subsubsection{Resistência à compressão}

Os resultados de resistência à compressão aos 7 e aos 28 dias estão apresentados na Figura 5. Para a análise da significância das variáveis controláveis - traço, teor de adição e idade de realização dos ensaios -, foi realizada uma Análise de Variância (ANOVA) com fatorial cruzada a partir do software Statistica 7. Os resultados são apresentados na Tabela 3 .

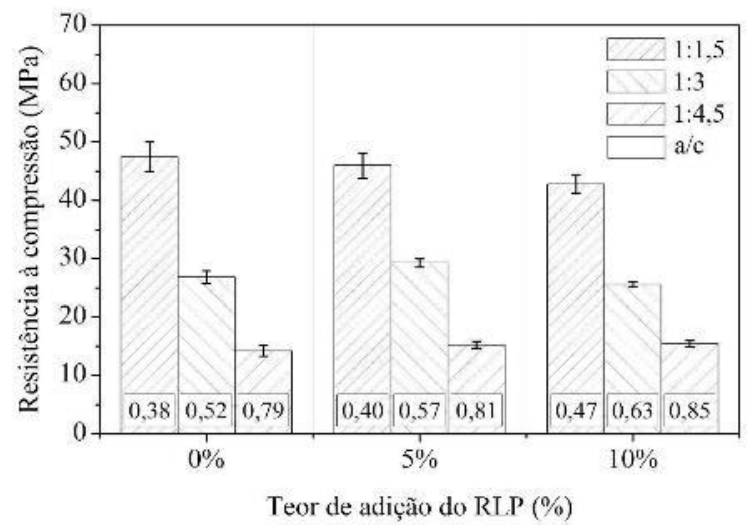

(a)

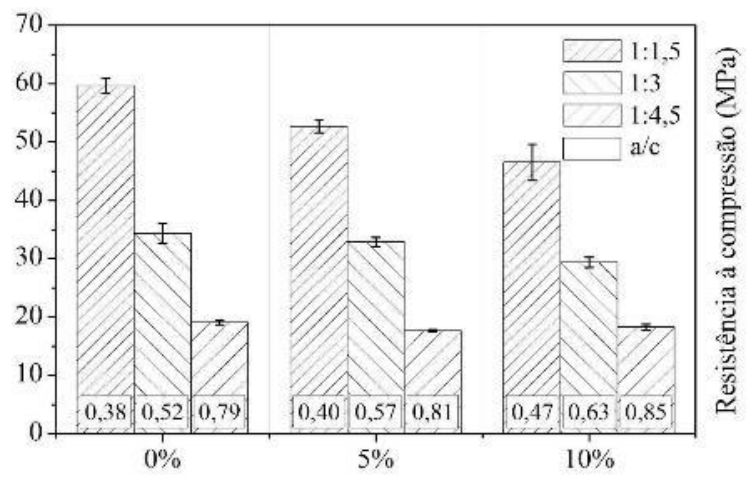

Teor de adição do RIP (\%)

(b)

Figura 5: Resistência à compressão (a) aos 7 dias, (b) aos 28 dias. 
Tabela 3: Análise de variância (ANOVA) - Resistência à compressão.

\begin{tabular}{l|l|l|l|l|l|l}
\hline EFEITOS & SQ & GL & SQF & TESTE F & P & SIG. \\
\hline Traço & 3962,12 & 1 & 71673,92 & 39116,77 & 0,000000 & Sim \\
\hline \% de adição & 3938,77 & 2 & 1981,06 & 1081,18 & 0,000000 & Sim \\
\hline Idade (dias) & 495,66 & 2 & 1969,39 & 1074,81 & 0,000000 & Sim \\
\hline Traço*\% de adição & 180,74 & 1 & 495,66 & 270,51 & 0,000000 & Sim \\
\hline Traço*Idade (dias) & 1730,67 & 4 & 45,19 & 24,66 & 0,000000 & Sim \\
\hline \% adição * idade (dias) & 3372,41 & 2 & 865,33 & 472,27 & 0,000000 & Sim \\
\hline Traço*\% de adição*Idade (dias) & 25,99 & 2 & 1686,20 & 920,26 & 0,000000 & Sim \\
\hline Erro & 97,11 & 4 & 6,50 & 3,55 & 0,012308 & -
\end{tabular}

SQ: Soma quadrática; GL: graus de liberdade (n-1); SQF: média quadrática; Teste F(calc): valor calculado de F; p: nível de significância; Se $\mathrm{p}<5 \%$ = efeito significativo

Uma vez que todos os efeitos tenham sido considerados significativos, foi realizado o teste F de Fisher onde foi verificado que no traço rico as argamassas produzidas com $0 \%$ e $5 \%$ não são diferentes estatisticamente. Também se observou esse efeito no traço intermediário, no qual os resultados obtidos para os teores de $0 \%$ e $10 \%$ de adição não são significativos entre si, e no traço pobre os três teores não são significativos estatisticamente.

As Figuras 6 e 7 demonstram a relação entre a relação água/cimento e a resistência à compressão para as idades de 7 e 28 dias, respectivamente. Observa-se, como esperado, que a resistência diminui com o aumento da relação água/cimento. Comparando o traço referência com o traço com $10 \%$ de adição, a resistência à compressão aos 7 dias (Figura 6b) aumentou, 22, 24 e 27\% para as relações água/cimento de 0,50, 0,60 e 0,70, respectivamente. Já aos 28 dias (Figura 7b), a resistência à compressão aumentou 5, 8 e $10 \%$ para as relações água/cimento de 0,50, 0,60 e 0,70, respectivamente. No trabalho de FRÍAS et al. [14] o ganho de resistência com a inserção do resíduo também foi evidenciado.

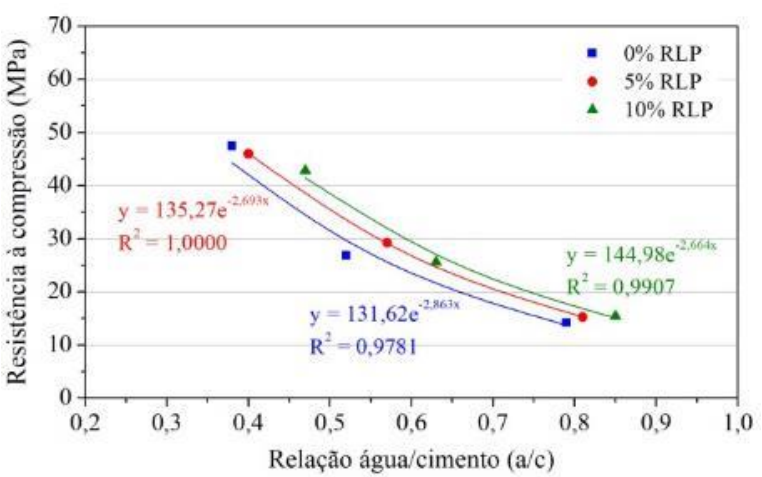

(a)

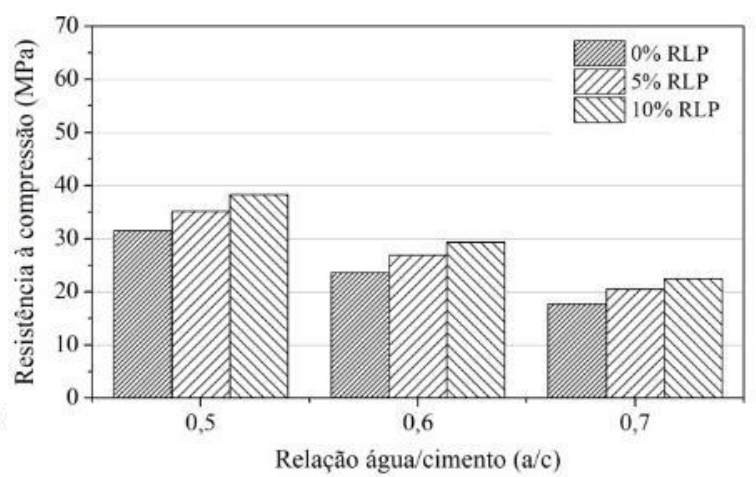

(b)

Figura 6: Idade de 7 dias (a) influência da relação água/cimento na resistência à compressão, (b) resistência à compressão em função da relação água/cimento estimada.

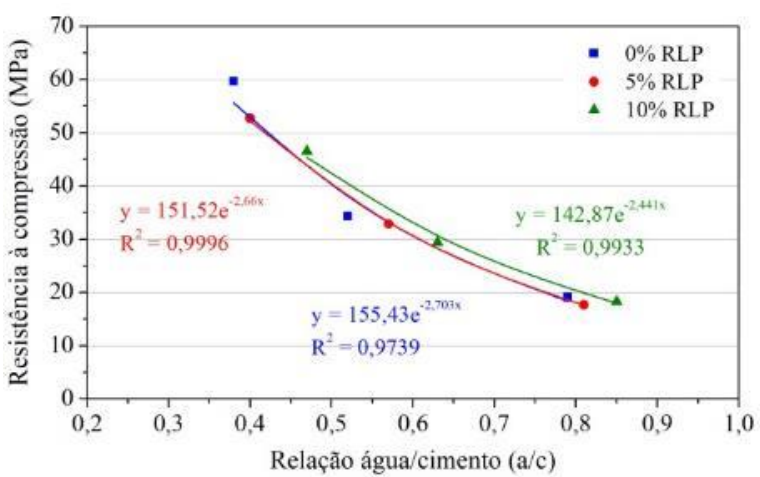

(a)

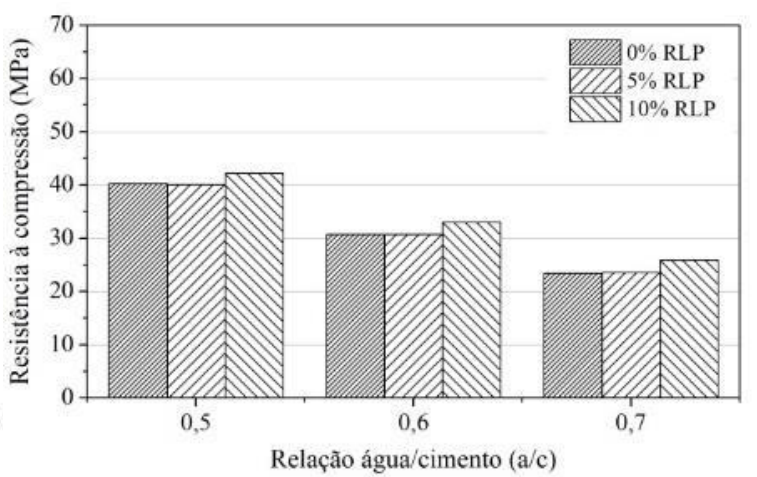

(b)

Figura 7: Idade de 28 dias (a) influência da relação água/cimento na resistência à compressão, (b) resistência à compressão estimada em função da relação água/cimento. 
A Figura 8 apresenta a relação entre a resistência à compressão e o consumo de cimento para a idade de 28 dias. É observado que para maiores resistências se tem um maior consumo de cimento, como esperado. Além disso, para maiores teores de adição de RLP o consumo de cimento necessário para atingir uma dada resistência é maior. Esse efeito fica mais evidente conforme o aumento da resistência.

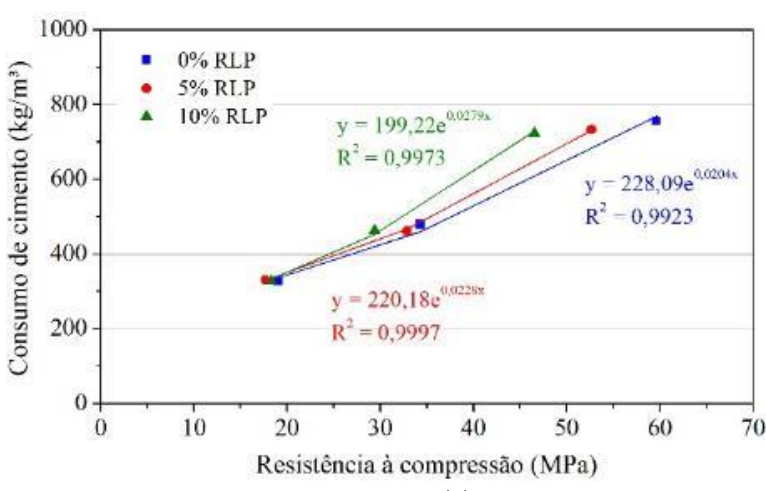

(a)

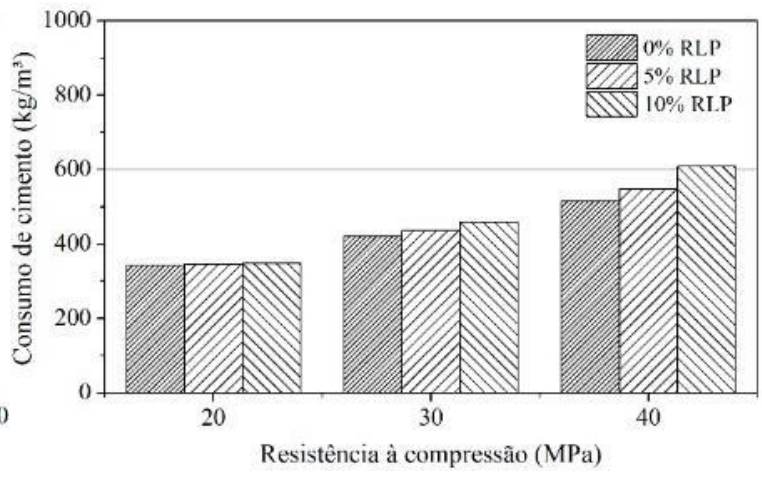

(b)

Figura 8: Idade de 28 dias (a) influência do consumo de cimento na resistência à compressão, (b) consumo de cimento estimado em função da resistência à compressão.

\subsubsection{Resistência à tração por compressão diametral}

Os resultados de resistência à tração por compressão diametral aos 28 dias estão apresentados na Figura 9. Para a análise da significância das variáveis controláveis, traço, teor de adição e idade de realização dos ensaios, foi realizada uma Análise de Variância (ANOVA) com fatorial cruzada a partir do software Statistica 7. Os resultados são apresentados na Tabela 4.

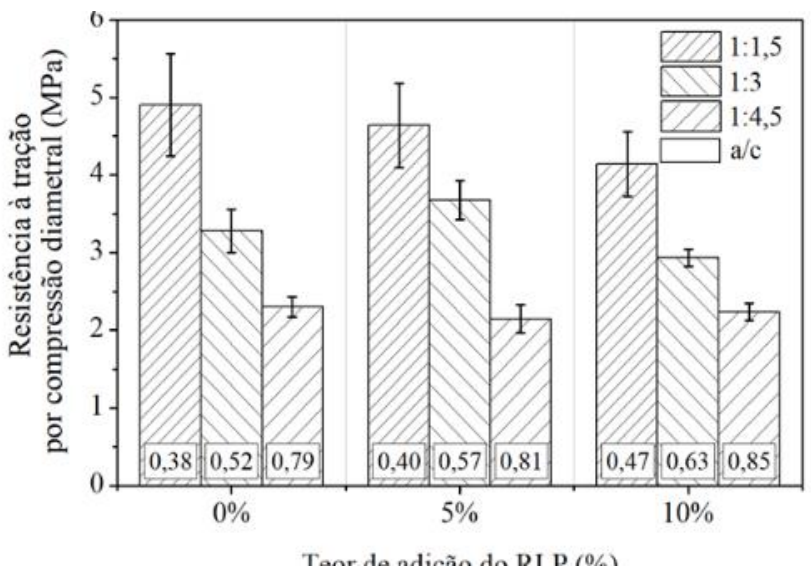

Figura 9: Resistência à tração na compressão diametral na idade de 28 dias.

Tabela 4: Análise de variância (ANOVA) - Resistência à tração por compressão diametral.

\begin{tabular}{l|l|l|l|l|l|l}
\hline EFEITOS & SQ & GL & SQF & TESTE F & P & SIG. \\
\hline Traço & 1,7955 & 2 & 0,8978 & 4,607 & 0,016544 & Sim \\
\hline Adição (\%) & 40,1361 & 2 & 20,0681 & 102,975 & 0,000000 & Sim \\
\hline Traço*Adição (\%) & 3,2730 & 4 & 0,8183 & 4,199 & 0,006832 & Sim \\
\hline Erro & 7,0158 & 36 & 0,1949 & - & - & - \\
\hline
\end{tabular}

SQ: Soma quadrática; GL: graus de liberdade (n-1); SQF: média quadrática; Teste $\mathrm{F}($ calc): valor calculado de $\mathrm{F}$; $\mathrm{p}$ : nível de significância; Se $\mathrm{p}<5 \%=$ efeito significativo

Embora todos os efeitos tenham sido considerados significativos, analisando através do teste de Fisher foi possível notar que as argamassas produzidas com o traço rico e o traço pobre não se mostraram estatisticamente significativas em nenhum dos teores de adição estudados. Para o traço intermediário, os teores de $5 \%$ e $10 \%$ de adição se mostraram significativos quando comparados entre si, porém ao serem comparados com a referência não se mostraram significativos.

A Figura 10a mostra a influência da adição do RLP na resistência à tração das argamassas. Observa-se 
que com o aumento da relação água/cimento a resistência à tração reduz. Na figura 10b, elaborada a partir das equações das curvas da Figura 10a, observa-se que não há uma alteração significativa da resistência à tração com a adição de RLP, tanto para o teor de $5 \%$ quanto para $10 \%$ de adição.

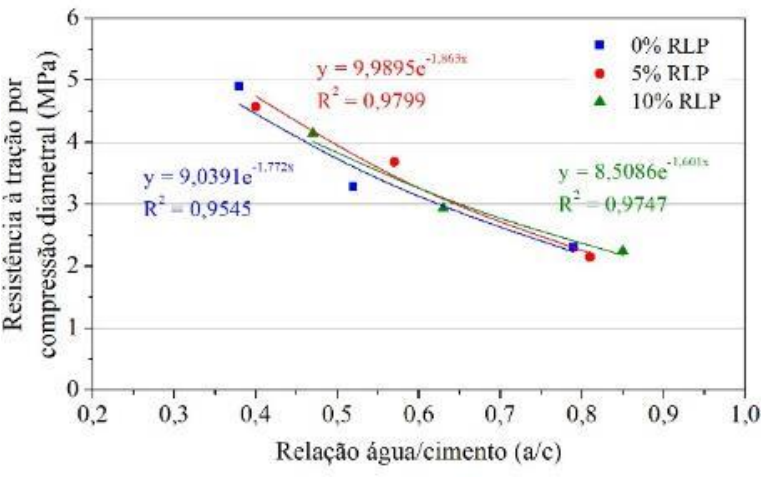

(a)

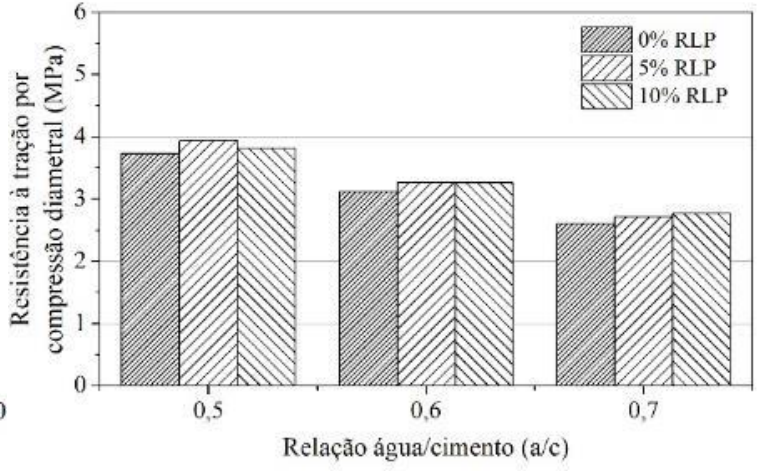

(b)

Figura 10: Idade de 28 dias (a) influência da relação água/cimento na resistência à tração por compressão, (b) resistência à tração por compressão diametral em função da relação água/cimento estimada.

\subsubsection{Densidade de Massa Aparente}

Os resultados obtidos no ensaio de densidade de massa aparente no estado endurecido dos corpos de prova em argamassa são apresentados na Figura 11. A média, desvio padrão e coeficiente de variação foram obtidas através do ensaio de quatro corpos de prova nas idades de 7 e 28 dias.

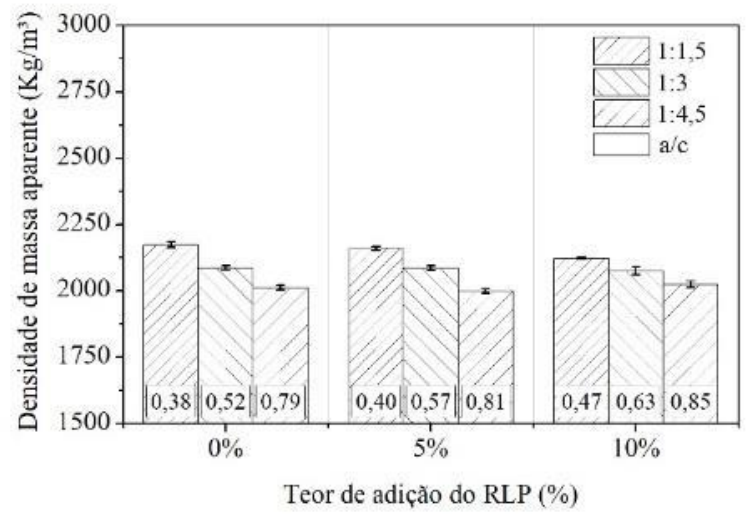

(a)

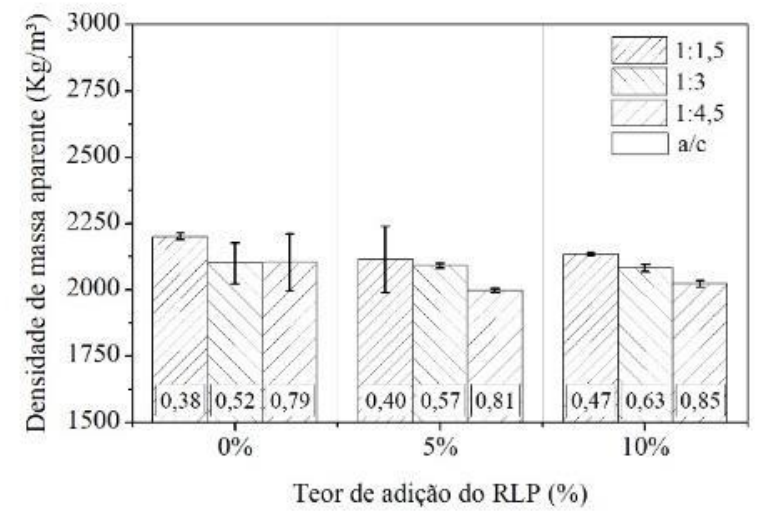

(b)

Figura 11: Densidade de Massa Aparente (a) aos 7 dias, (b) 28 dias.

Para a análise da significância das variáveis controláveis, traço, teor de adição e idade de realização dos ensaios, foi realizada uma Análise de Variância (ANOVA) com fatorial cruzada a partir do software Statistica 7. Os resultados são apresentados na Tabela 5.

Tabela 5: Análise de variância (ANOVA) - Densidade de massa aparente.

\begin{tabular}{l|l|l|l|l|l|l}
\hline EFEITOS & SQ & GL & SQF & TESTE F & P & SIG. \\
\hline Traço & 79946 & 2 & 39973 & 415 & 0,000000 & Sim \\
\hline \% de adição & 93723 & 2 & 46862 & 486 & 0,000000 & Sim \\
\hline Idade (dias) & 1157 & 1 & 1157 & 12 & 0,001050 & Sim \\
\hline Traço*\% de adição & 10469 & 4 & 2617 & 27 & 0,000000 & Sim \\
\hline Traço*Idade (dias) & 41609 & 2 & 20804 & 216 & 0,000000 & Sim \\
\hline \% adição * idade (dias) & 61756 & 2 & 30878 & 320 & 0,000000 & Sim \\
\hline Traço*\% de adição*Idade (dias) & 2225 & 4 & 556 & 6 & 0,000610 & Sim \\
\hline Erro & 5205 & 54 & 96 & & & - \\
\hline
\end{tabular}

SQ: Soma quadrática; GL: graus de liberdade (n-1); SQF: média quadrática; Teste F(calc): valor calculado de F; p: nível de significância; Se p $<5 \%=$ efeito significativo 
As Figuras 12 e 13 apresentam a influência da adição de RLP na densidade de massa aparente, para diferentes relações água/cimento, para as idades de 7 e 28 dias, respectivamente.

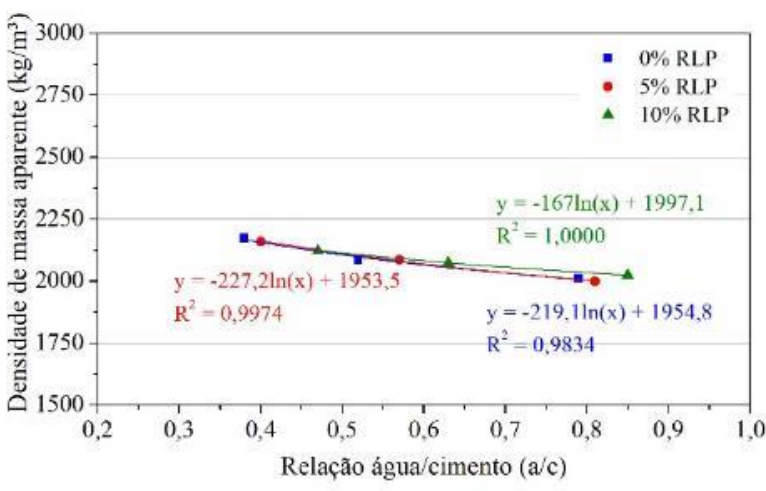

(a)

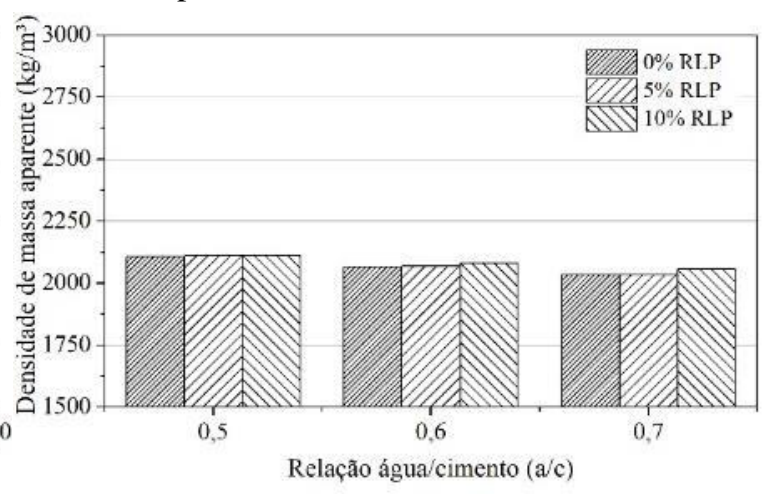

(b)

Figura 12: Idade de 7 dias (a) influência da relação água/cimento na densidade de massa aparente, (b) densidade de massa aparente em função da relação água/cimento estimada.

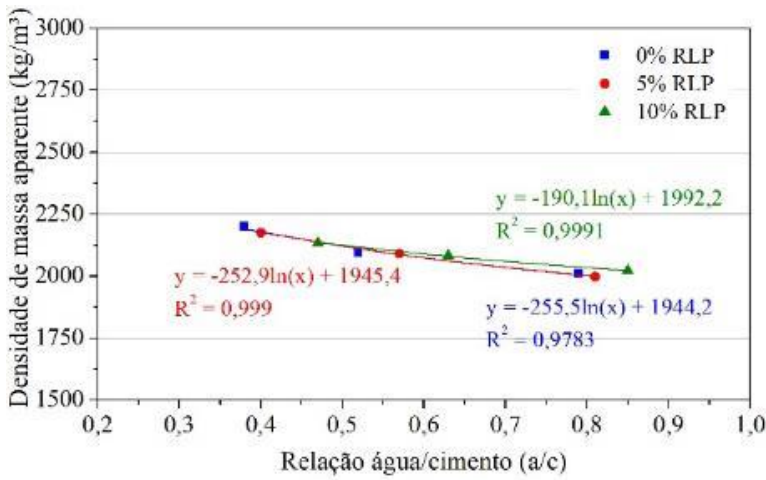

(a)

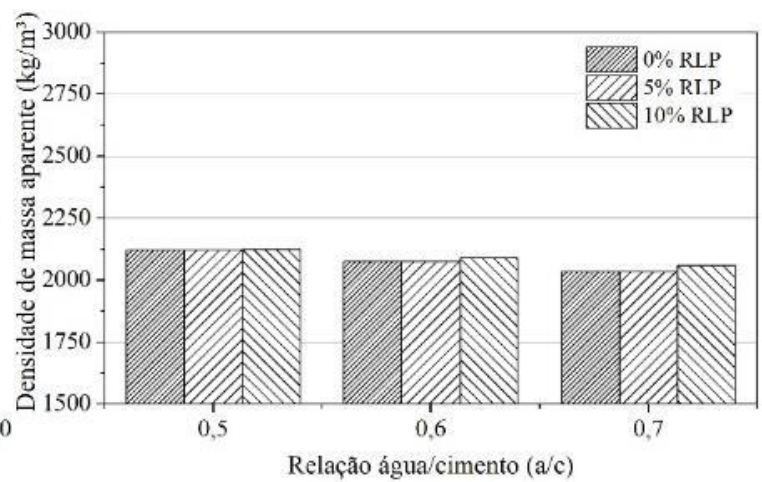

(b)

Figura 13: Idade de 28 dias (a) influência da relação água/cimento na densidade de massa aparente, (b) densidade de massa aparente em função da relação água/cimento estimada.

Observa-se nas Figuras 12a e 13a que com o aumento da relação água/cimento a densidade de massa aparente reduz. Na figura 12b, elaborada a partir das equações das curvas da Figura 12a, para a mesma relação água/cimento é possível notar que a densidade de massa aparente aumenta com a adição do RLP. Segundo Dal Molin [41], um dos efeitos físicos que pode ser ocasionado pelas adições minerais é efeito fíler, que em função do preenchimento dos vazios pelas partículas da adição acarreta um aumento na densidade das misturas, corroborando com o fato encontrado nesta pesquisa.

Já na idade de 28 dias (Figura 13b) percebe-se que com a adição de 5\% de resíduo a densidade não foi alterada significativamente, apenas para a adição de $10 \%$ é perceptível um aumento real, mais significativo quanto maior a relação a/c.

\subsubsection{Módulo de elasticidade dinâmico}

Os resultados obtidos no ensaio de módulo de elasticidade dinâmico dos corpos de prova em argamassa são apresentados na Figura 14. A média, desvio padrão e coeficiente de variação foram obtidas através do ensaio de quatro corpos de prova, na idade de 7 dias e 28 dias.

Para a análise da significância das variáveis controláveis, traço e teor de adição e idade de realização dos ensaios, foi realizada uma Análise de Variância (ANOVA) com fatorial cruzada a partir do software Statistica 7. Os resultados são apresentados na Tabela 6. 


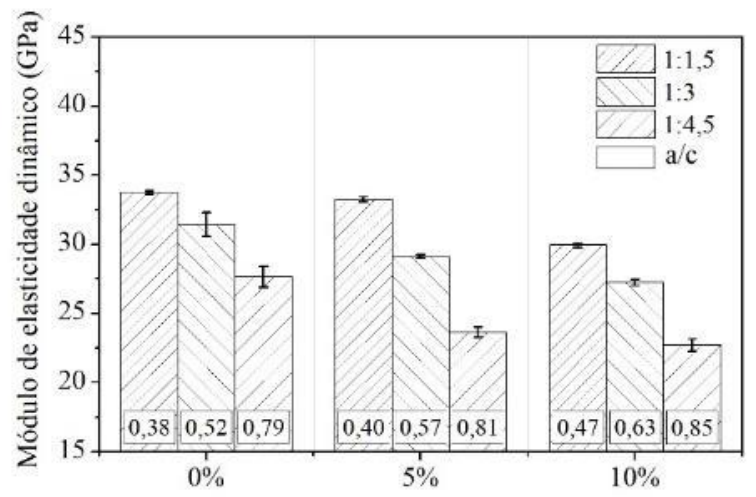

Teor de adição do RLP (\%)

(a)

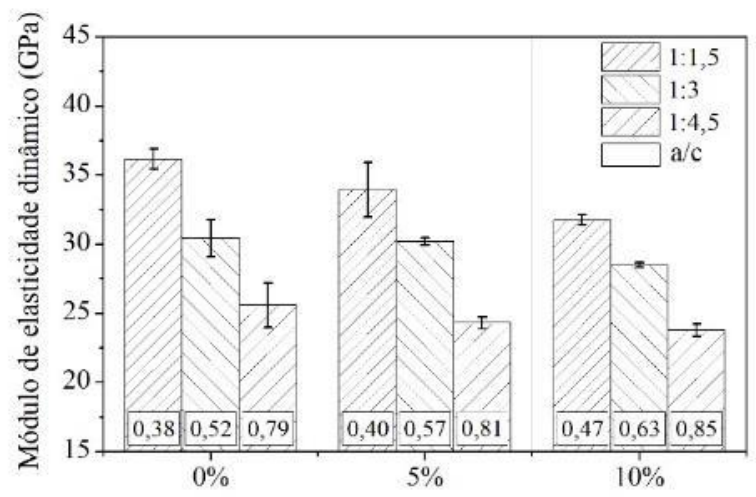

Teor de adição do RLP (\%)

(b)

Figura 14: Módulo de elasticidade dinâmico (a) aos 7 dias, (b) aos 28 dias.

Tabela 6: Análise de variância (ANOVA) - Módulo de elasticidade dinâmico.

\begin{tabular}{l|l|l|l|l|l|l}
\hline EFEITOS & SQ & GL & SQF & TESTE F & P & SIG. \\
\hline Traço & 388,87 & 2 & 194,44 & 1465,7 & 0,000000 & Sim \\
\hline \% de adição & 471,88 & 2 & 235,94 & 1778,5 & 0,000000 & Sim \\
\hline Idade (dias) & 30,58 & 1 & 30,58 & 230,5 & 0,000000 & Sim \\
\hline Traço*\% de adição & 21,87 & 4 & 5,47 & 41,2 & 0,000000 & Sim \\
\hline Traço*Idade (dias) & 132,42 & 2 & 66,21 & 499,1 & 0,000000 & Sim \\
\hline \% adição * idade (dias) & 180,55 & 2 & 90,28 & 680,5 & 0,000000 & Sim \\
\hline Traço*\% de adição*Idade (dias) & 3,13 & 4 & 0,78 & 5,9 & 0,000513 & Sim \\
\hline Erro & 7,16 & 54 & 0,13 & & & - \\
\hline
\end{tabular}

As Figuras 15 e 16 mostram a influência da adição do RLP nas argamassas. Observa-se que com o aumento da relação água/cimento o módulo de elasticidade reduz; consequente essas argamassas serão mais deformáveis do que as que possuem menores relações água/cimento.

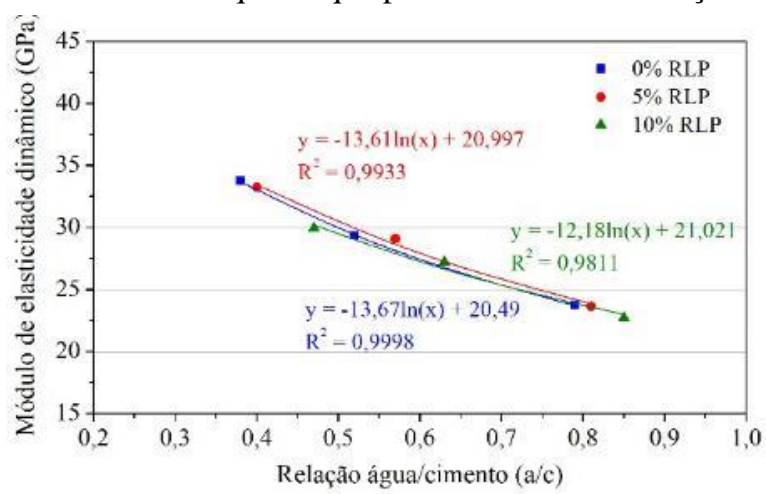

(a)

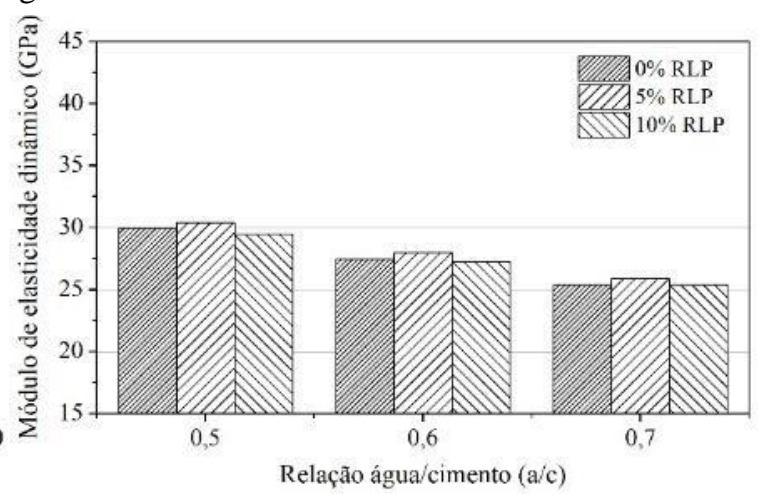

(b)

Figura 15: Módulo de elasticidade dinâmico aos 7 dias em função de diferentes relações água/cimento. 


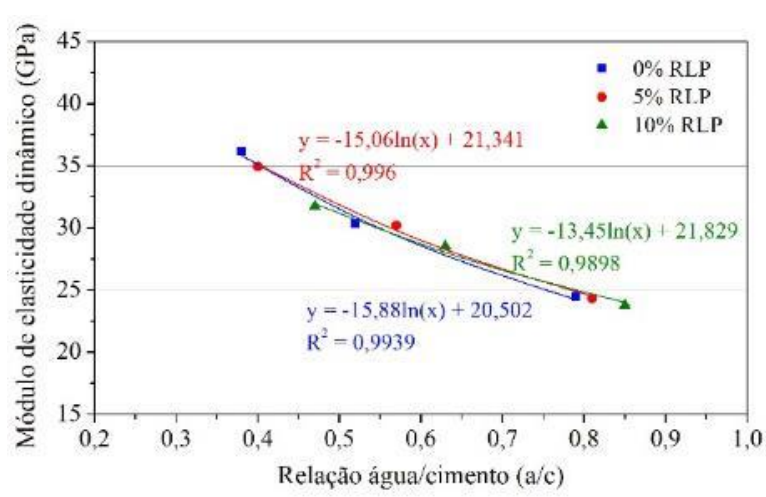

(a)

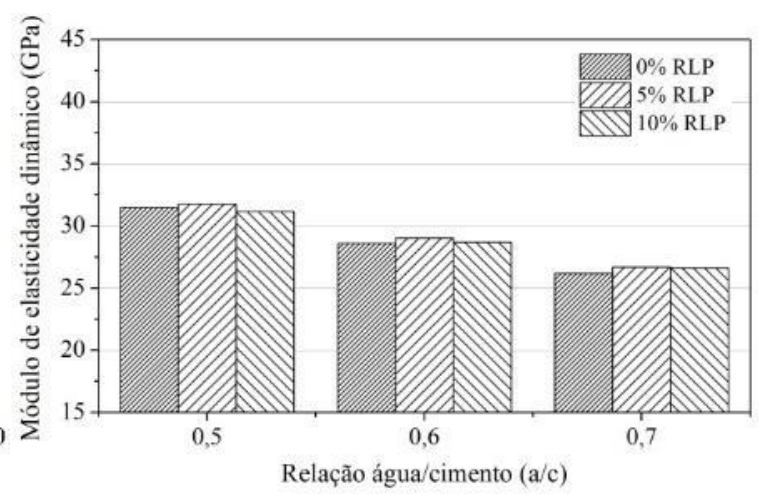

(b)

Figura 16: Módulo de elasticidade dinâmico aos 28 dias em função de diferentes relações água/cimento.

Embora quando realizada a análise de variância todos os fatores tenham sido considerados significativos, logo influenciam a propriedade estudada, quando fixadas as relações água/cimento não é possível afirmar que a adição do RLP tenha provocado aumento ou redução na propriedade em análise, uma vez que a maior redução observada vai de $1,14 \%$ para o teor de $5 \%$ na relação a/c de 0,5 e o maior incremento foi de $2,09 \%$ para o teor de $5 \%$ na relação a/c de 0,7 .

\subsubsection{Absorção de água por capilaridade}

A Figura 17 mostra a influência da adição do resíduo na absorção de água por capilaridade nos teores de 5 e $10 \%$ para os diferentes traços estudados.
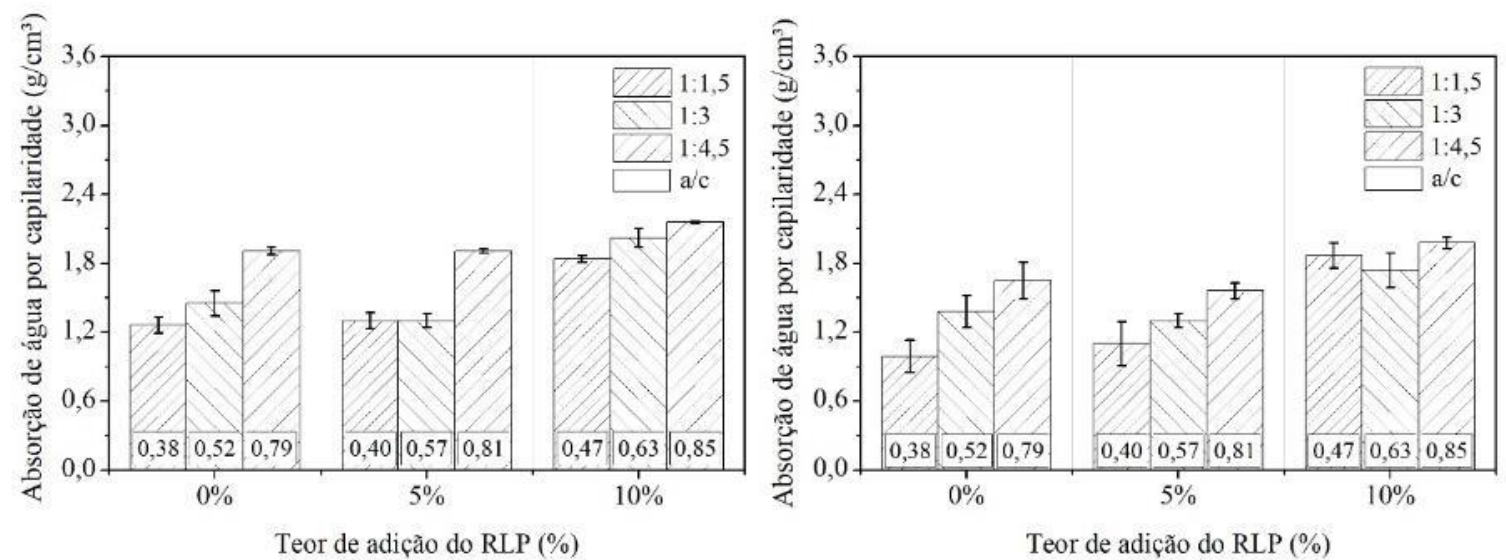

Figura 17: Absorção de água por capilaridade (a) aos 7 dias, (b) aos 28 dias.

Para a análise da significância das variáveis controláveis, traço e teor de adição, foi realizada uma Análise de Variância (ANOVA) com fatorial cruzada a partir do software Statistica 7. Os resultados são apresentados na Tabela 7. Todos os efeitos avaliados foram considerados significativos.

Tabela 7: Análise de variância (ANOVA) - Absorção de água por capilaridade às 96 horas.

\begin{tabular}{l|l|l|l|l|l|l}
\hline EFEITOS & SQ & GL & SQF & TESTE F & P & SIG. \\
\hline Traço & 2,9830 & 2 & 1,4915 & 147,21 & 0,000000 & Sim \\
\hline$\%$ de adição & 2,0686 & 2 & 1,0343 & 102,09 & 0,000000 & Sim \\
\hline Idade (dias) & 0,4050 & 1 & 0,4050 & 39,97 & 0,000000 & Sim \\
\hline Traço*\% de adição & 0,3625 & 4 & 0,0906 & 8,95 & 0,000040 & Sim \\
\hline Traço*Idade (dias) & 0,0608 & 2 & 0,0304 & 3,00 & 0,062332 & Não \\
\hline \% adição * idade (dias) & 0,1506 & 2 & 0,0753 & 7,43 & 0,001986 & Sim \\
\hline Traço*\% de adição*Idade (dias) & 0,1468 & 4 & 0,0367 & 3,62 & 0,014009 & Sim \\
\hline Erro & 0,3647 & 36 & 0,0101 & & & - \\
\hline
\end{tabular}

SQ: Soma quadrática; GL: graus de liberdade (n-1); SQF: média quadrática; Teste F(calc): valor calculado de F; p: nível de significância; Se $\mathrm{p}<5 \%$ = efeito significativo 
Embora todas as variáveis tenham sido consideradas significativas, foi realizado o teste F de Fischer onde foi observado que para o traço rico, os teores de 0 e 5\% de RLP não são significativos entre si, isso também foi observado para o traço pobre nos mesmos teores.

Nas Figuras 18 e 19 pode-se observar que a absorção de água por capilaridade aumenta conforme a relação água/cimento, conforme esperado. Quando realizada a comparação em igualdade de relação água/cimento, observa-se que para todas as relações houve comportamento semelhante entre as misturas, onde o teor de $5 \%$ provocou uma redução de 5,36\% quando comparado ao traço de referência. Já o teor de $10 \%$ aumentou a absorção em comparação ao traço referência em $24,65 \%, 19,93 \%$ e 14,93\% para as relações água/cimento de $0,5,0,6$ e 0,7 respectivamente, efeito considerado negativo.

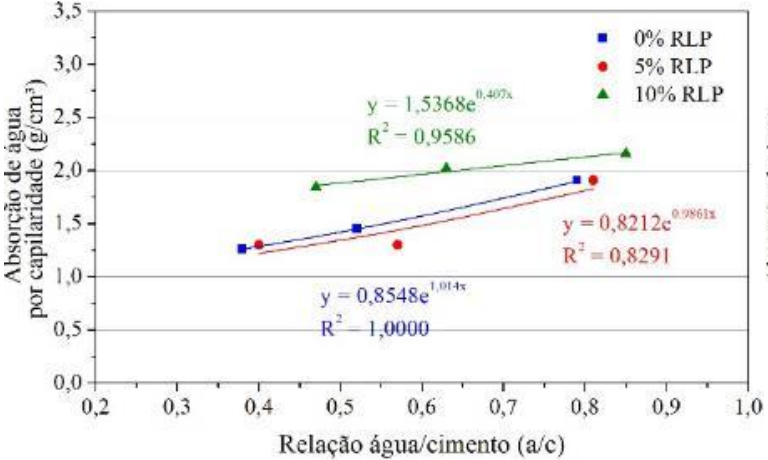

(a)

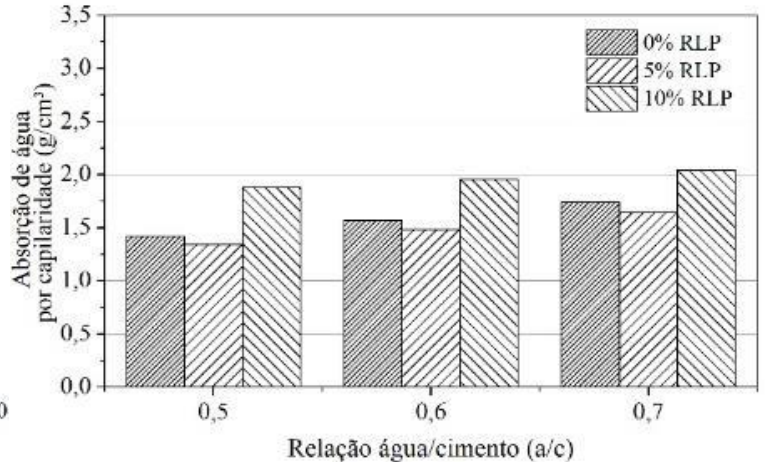

(b)

Figura 18: Absorção de água por capilaridade às 96 horas em função de diferentes relações água/cimento aos 7 dias.

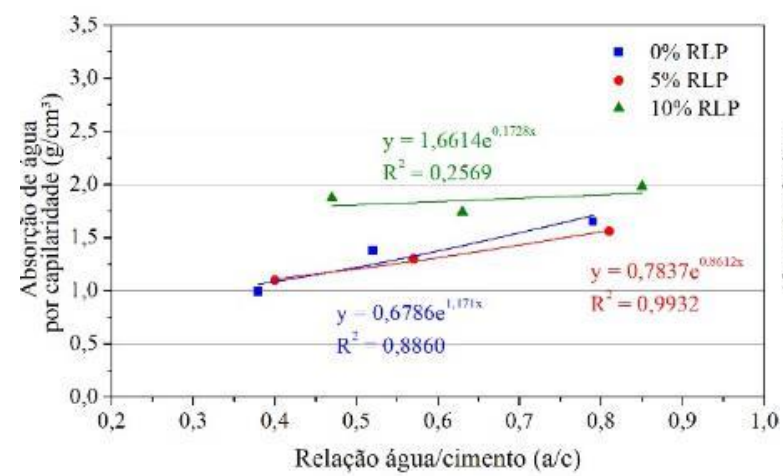

(a)

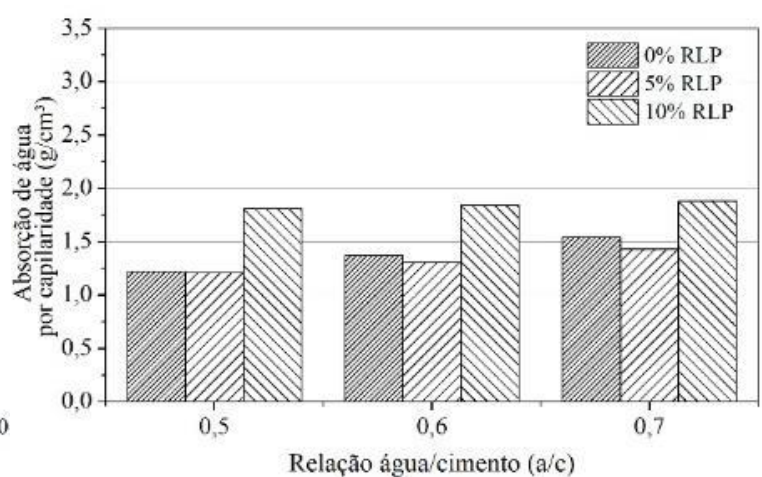

(b)

Figura 19: Absorção de água por capilaridade às 96 horas em função de diferentes relações água/cimento aos 28 dias.

Esse resultado diverge do encontrado por COURARD e MICHEL [42], que avaliaram a substituição de parte do cimento por fíler calcário em argamassas. Os autores observaram incremento na absorção de água para teores de substituição de até $15 \%$ e, a partir deste, observou-se uma redução na absorção até o teor máximo de substituição avaliado, de 30\%.

\section{CONCLUSÕES}

Neste trabalho foi utilizado um resíduo proveniente do lodo de efluentes de uma indústria de papel tissue empregado como fíler em uma argamassa cimentícia. O resíduo provocou um aumento no fluxo de calor para os dois teores empregados sendo os maiores fluxos de calor evidenciados para o teor de $10 \%$ nas primeiras horas. A respeito do proporcionamento dos materiais, todas as argamassas produzidas com a adição do RLPC tiveram um aumento na relação água/cimento para o mesmo abatimento $(250 \pm 10 \mathrm{~mm})$ e o consumo de cimento aumentou para os dois teores de adição do resíduo em igualdade de resistência. Quanto à resistência à compressão, o teor de $10 \%$ de adição do resíduo se mostrou mais eficiente, aumentando a resistência em todas as relações a/c estudadas. Para a resistência à compressão por tração diametral, o RLP aumentou a resistência para os dois teores de adição. Já para a densidade de massa aparente, nas relações a/c abaixo de 0,55 o resíduo praticamente não apresentou alterações, mas para relações mais altas a adição de $10 \%$ de resíduo provocou um incremento na propriedade. No teor de 5\% não há evidente alteração na densidade de massa aparente. Quanto ao módulo de elasticidade dinâmico, a maior quantidade de adição RLP causou 
redução do módulo. Por fim, com relação à absorção de água por capilaridade, o teor de 5\% se mostrou melhor, uma vez que provocou uma redução na absorção. Apesar da adição de RLP ter apresentado efeitos positivos sobre algumas propriedades das argamassas, como o aumento na resistência à compressão e na resistência à compressão diametral, e ter diminuído a absorção de água para o teor de 5\%, este resíduo também provocou um aumento no consumo de cimento para atingir a resistência requerida e um aumento no consumo de água para obter uma mesma consistência. Os autores concluem, portanto, que o resíduo investigado neste trabalho não é adequado para emprego em matrizes cimentícias nas condições aqui utilizadas. Recomenda-se testar o resíduo com o uso de aditivos plastificantes, pois se admite que possa ter havido aglomeração das partículas, prejudicando o desempenho.

\section{AGRADECIMENTOS}

Agradecemos ao Laboratório de Materiais e Tecnologia do Ambiente Construído (LAMTAC), inserido no Núcleo Orientado para a Inovação da Edificação (NORIE) pelo espaço e disponibilidade dos equipamentos para a realização desta pesquisa. E a empresa produtora de papeis tissue pelo fornecimento do resíduo.

\section{BIBLIOGRAFIA}

[1] PILAR, R., SCHANKOSKI, R. A., DAL MORO, A. J., et al., "Avaliação de pastas de cimento Portland contendo cinza pesada moída”, Matéria, v. 21, n. 01, pp. 92-104, 2016.

[2] Indústria Brasileira de Árvores (IBÁ), Relatório Anual 2016, http://iba.org/images/shared/Biblioteca/IBA_RelatorioAnual2016_.pdf. Acesso em agosto de 2017.

[3] ANGUTI Estatística. ANG03 - Papéis de Fins Sanitários - Informativo mensal, http://www.anguti.com.br/solucoes. Acesso em agosto de 2017.

[4] ERENO, D. "Lodo da indústria de papel entra na composição de materiais de construção", Revista Pesquisa FAPESP, v. 161, pp. 78-79, Jul. 2009.

[5] LÉBEIS, V. D. L., "Viabilidade do uso do resíduo da fabricação do papel em argamassas", Dissertação de M. Sc., Universidade Estadual de Campinas, Campinas, SP, 2003.

[6] PAIVA, S. N., "Compósitos cimento-lodo de ETE de indústria de papel para aplicação na construção civil”, Dissertação M. Sc., USP, São Paulo, SP, 2007.

[7] VIEIRA, C. M. F., PINHEIRO, R. M., RODRIGUEZ, R. J. S., et al., "Clay bricks added with effluent sludge from paper industry: Technical, economical and environmental benefits", Applied Clay Science, v. 132-133, pp. 753-759, 2016.

[8] CUSIDÓ, J. A., CREMADES, L. V., SORIANO, C., et al., "Incorporation of paper sludge in clay brick formulation: Ten years of industrial experience”, Applied Clay Science, v. 108, pp. 191-198, 2015.

[9] DE LA VILLA, R. V., FRÍAS, M., ROJAS, M. I. S., et al., "Mineralogical and morphological changes of calcined paper sludge at different temperatures and retention in furnace", Applied Clay Science, v. 36, pp. 279-286, 2007.

[10] PERA, J., AMROUZ, A., "Development of Highly Reactive Metakaolin from Paper Sludge”, Advanced Cement Based Materials, v. 7, pp. 49-56, 1998.

[11] BANFILL, P., FRÍAS, M. "Rheology and conduction calorimetry of cement modified with calcined paper sludge", Cement and Concrete Research, v. 37, pp. 184-190, 2007.

[12] VEGAS, I., FRÍAS, M., URRETA, J., et al., "Obtaining a pozzolanic addition from the controlled calcination of paper mill sludge. Performance in cement matrices", Materiales de Construcción, v. 56, pp. 49-60, 2006.

[13] GARCÍA, R., DE LA VILLA, R. V., VEGAS, I., et al., "The pozzolanic properties of paper sludge waste", Construction and Building Materials, v. 22, pp. 1484-1490, 2008.

[14] FRÍAS, M., RODRÍGUEZ, O., VEGAS, I., VIGIL, R., "Properties of Calcined Clay Waste and its Influence on Blended Cement Behavior", The American Ceramic Society, v. 91, pp. 1226-1230, 2008.

[15] AHMADI, B., AL-KHAJA, W., "Utilization of paper waste sludge in the building construction industry”, Resources, Conservation and Recycling, v. 32, pp. 105-113, 2001.

[16] FRÍAS, M., DE ROJAS, M. I. S., RODRÍGUEZ, O., et al., "Characterisation of calcined paper sludge as an environmentally friendly source of metakaolin for manufacture of cementitious materials", Advances in Cement Research, v. 7605, pp. 23-30, 2008b. 
[17] ASSOCIAÇÃO BRASILEIRA DE NORMAS TÉCNICAS. NBR 248: agregados - determinação da composição granulométrica. Rio de Janeiro, 2003.

[18] ASSOCIAÇÃO BRASILEIRA DE NORMAS TÉCNICAS. NBR 7211: agregado para concreto especificação. Rio de Janeiro, 2009.

[19] ASSOCIAÇÃO BRASILEIRA DE NORMAS TÉCNICAS. NBR NM 52: agregado miúdo determinação da massa específica e massa específica aparente. Rio de Janeiro, 2009.

[20] MOURA, W. A., "Utilização de escória de cobre como adição e como agregado miúdo para concreto", Tese D. Sc., UFRGS, Porto Alegre, RS, 2000.

[21] MASUERO, A. B., "Estabilização das escórias de aciaria elétrica com vistas a sua utilização como substituição ao cimento", Tese D. Sc., UFRGS, Porto Alegre, RS, 2001.

[22] GIORDANI, C., "Viabilidade técnica do uso de resíduos do beneficiamento de arenito como substituição do agregado miúdo em argamassas", Trabalho de conclusão de curso, UFRGS, Porto Alegre, RS, 2014.

[23] PETRY, N. S., "Avaliação do resíduo de ágata como agregado em argamassas de cimento Portland branco", Dissertação M. Sc., UFRGS, Porto Alegre, RS, 2015.

[24] ASSOCIAÇÃO BRASILEIRA DE NORMAS TÉCNICAS. NBR 7215: cimento Portland determinação da resistência à compressão. Rio de Janeiro, 1997.

[25] ASSOCIAÇÃO BRASILEIRA DE NORMAS TÉCNICAS. NBR 13276: argamassa para assentamento e revestimento de paredes e tetos - determinação do índice de consistência. Rio de Janeiro, 2016.

[26] ASSOCIAÇÃO BRASILEIRA DE NORMAS TÉCNICAS. NBR 5739: concreto - ensaios de compressão de corpos de prova cilíndricos. Rio de Janeiro, 2007.

[27] ASSOCIAÇÃO BRASILEIRA DE NORMAS TÉCNICAS. NBR 7222: concreto e argamassa determinação da resistência à tração por compressão diametral de corpos de prova cilíndricos. Rio de Janeiro, 2011.

[28] ASSOCIAÇÃO BRASILEIRA DE NORMAS TÉCNICAS. NBR 9779: argamassa e concreto endurecidos - determinação da absorção de água por capilaridade. Rio de Janeiro, 2012.

[29] ASSOCIAÇÃO BRASILEIRA DE NORMAS TÉCNICAS. NBR 13280: argamassa para assentamento e revestimento de paredes e tetos - determinação da densidade de massa aparente no estado endurecido. Rio de Janeiro, 2005.

[30] ASSOCIAÇÃO BRASILEIRA DE NORMAS TÉCNICAS. NBR 15630: argamassa para assentamento e revestimento de paredes e tetos - determinação do módulo de elasticidade dinâmico através da propagação de onda ultrassônica. Rio de Janeiro, 2008.

[31] VENQUIARUTO, S., OSSORIO, A., ZANINI, C., et al., "Aproveitamento de Resíduos de Ágata Reciclada em Materiais Cimentícios Sustentáveis”, In: HARTMANN, L. A. et al. (Orgs.). Tecnologia e Inovação em Gemas, Joias e Mineração. 1. ed., Porto Alegre: IGeo/UFRGS, pp. 99-106, 2014.

[32] FIGUEROA, M. J. M., MORAES, P. D., "Comportamento da madeira a temperaturas elevadas", Revista Ambiente Construído, v.9, pp. 157-174, Dez. 2009.

[33] GUAITOLINI, M. "Estudo da queima de lodo secundário da indústria de celulose em caldeira de leito fluidizado”, Dissertação M. Sc., Universidade Federal de Viçosa, Viçosa, MG, 2014.

[34] SCHAFFER, E. L., "Effect of Pyrolytic Temperatures on the Longitudinal Strength of Dry Douglas Fir", Journal of Testing and Evaluation, v. 1, n. 4, pp. 319-329, 1973.

[35] HOPPE FILHO, J., GOBBI, A., PEREIRA, E., et al., "Atividade Pozolânica de Adições Minerais para Cimento Portland (Parte I): Índice de Atividade Pozolânica (IAP) com Cal, Difração de Raios-X (DRX), Termogravimetria (TG/DTG) e Chapelle Modificado", Matéria, v.22, n. 3, 2017.

[36] LOTHENBACH, B., DURDZINSKI, P., WEERDT, K., "Thermogravimetric analysis", In: Scrivener, K., Snellings, R., Lothenbach, B., (eds), A Practical Guide to Microstructural Analysis of Cementitious Materials, 1 ed, chapter 5, Boca Raton, FL, USA, Taylor \& Francis Group, 2016.

[37] KAKALI, G., PERRAKI, T., TSIVILIS, S., et al., "Thermal treatment of kaolin: the effect of mineralogy on the pozzolanic activity", Applied Clay Science, v. 20, pp. 73-80, 2001.

[38] SNELLINGS, R., MERTENS, G., ELSEN, J. "Supplementary Cementitious Materials", Reviews in Mineralogy and Geochemistry, v. 74, n. 1, pp. 211-278, 2012. 
[39] LOTHENBACH, B., SCRIVENER, K., HOOTON, R. D., "Supplementary cementitious materials", Cement and Concrete Research, v. 41, pp. 1244-1256, 2011.

[40] MARANGON, E., "Desenvolvimento e caracterização de concretos autoadensáveis reforçados com fibra de aço”, Dissertação M. Sc., UFRJ, Rio de Janeiro, RJ, 2006.

[41] DAL MOLIN, D. C. C., “Adições Minerais”, In ISAIA, G.C. Concreto: Ciência e tecnologia, v. I-II. São Paulo, IBRACON, 2011.

[42] COURARD, L., MICHEL, F., "Limestone filler cement based composites: Effects of blast furnace slags on fresh and hardened properties", Construction and Building Materials, v. 51, pp. 439-445, 2014.

\section{ORCID}

Vanessa Giaretton Cappellesso

Natália dos Santos Petry

Camila Salvi Malacarne

Gustavo Filipe dos Santos

Ana Paula Kirchheim

Angela Borges Masuero

Denise Carpena Coitinho Dal Molin

Erich David Rodriguez http://orcid.org/0000-0002-3886-6884

http://orcid.org/0000-0003-1634-0176

http://orcid.org/0000-0003-4952-9629

http://orcid.org/0000-0002-5431-676X

http://orcid.org/0000-0002-8241-0331

http://orcid.org/0000-0001-9117-8346

http://orcid.org/0000-0003-1934-7533

http://orcid.org/0000-0003-1914-4541 